\title{
HARMONISASI KEBIJAKAN HULU-HILIR DALAM PENGEMBANGAN BUDIDAYA DAN INDUSTRI PENGOLAHAN KAKAO NASIONAL
}

\author{
(Upstream-Downstream Policy Harmonization In The Development \\ of Cultivation and National Cocoa Processing Industry)
}

\author{
Daru Mulyono \\ Pusat Teknologi Produksi Pertanian, BPPT \\ Gedung LAPTIAB No. 612, Jl. Raya Puspiptek \\ Kawasan Perkantoran Puspiptek Serpong, Tangerang Selatan, Banten \\ Email: darumulyono@yahoo.com
}

Naskah diterima: 10 Februari 2016

Naskah direvisi: 26 Februari 2016

Naskah diterbitkan: 30 Desember 2016

\begin{abstract}
Cocoa productivity in Indonesia is relatively low as it was recorded in 2013 production of cocoa beans that reached only $414 \mathrm{~kg} / \mathrm{ha} /$ year. This was far below the ideal average that may reach 2,000 kg/ha/year. Similarly, in the cocoa processing industry is experiencing difficulties due to shortage of raw material supply cocoa beans that have not been optimally developed. The objective of study is to obtain a clearer understanding of the national cocoa agribusiness development conducted through the policy harmonization upstreamdownstream in the development of cocoa cultivation and cocoa processing industry. This study is an analytical descriptive study with data analysis carried out through (a) a review of policy documents related to the development of cocoa and (b) the formulation of a concept for improving cocoa production and developing the cocoa processing industry in the country. In order to support national cocoa agribusiness development, the government has implemented Gernas Cocoa Program to increase cocoa production and to impose the Export Duty of cocoa beans regulation through Finance Minister Regulation No. 67/PMK.011/2010 to ensure the supply of raw cocoa beans in the cocoa processing industry. The result of Gernas Cocoa Program and Export Duty of cocoa beans implementation shows that volume of cocoa beans exports continues to fall and by contrast the volume processed cocoa exports continue to rise. The impact of these policies will be more evident in the development of agribusiness cocoa when it is done through harmonious and synergetic policy formulation in the aspects of both cocoa cultivation (upstream) and cocoa processing industry (downstream).

Keywords: cocoa cultivation, processing, cocoa agribusiness, industrial policy
\end{abstract}

\begin{abstract}
Abstrak
Produktivitas kakao di Indonesia tergolong rendah, tercatat pada tahun 2013 produksi biji kakao hanya mencapai $414 \mathrm{~kg} / \mathrm{ha} / \mathrm{tahun}$ jauh di bawah rata-rata ideal yang mencapai $2.000 \mathrm{~kg} / \mathrm{ha} / \mathrm{tahun}$. Demikian pula dalam industri pengolahan kakao yang mengalami kesulitan karena kekurangan pasokan bahan baku biji kakao sehingga belum berkembang optimal. Kajian ini bertujuan untuk memperoleh pemahaman yang lebih jelas dalam upaya pengembangan agribisnis kakao nasional yang dilakukan melalui harmonisasi dan sinkronisasi kebijakan hulu-hilir dalam pengembangan budidaya dan industri pengolahan kakao. Kajian ini merupakan kajian deskriptif analitik dengan analisis data dilakukan melalui (a) penelaahan dokumen-dokumen kebijakan yang terkait dengan pengembangan kakao dan (b) perumusan konsep untuk meningkatkan produksi kakao dan mengembangkan industri pengolahan kakao dalam negeri. Untuk menunjang upaya pengembangan agribisnis kakao tersebut pemerintah telah melaksanakan program peningkatan produksi kakao melalui Gernas Kakao dan untuk pengembangan industri pengolahan kakao pemerintah telah pula menerapkan kebijakan pengenaan Bea Keluar ekspor biji kakao melalui Peraturan Menteri Keuangan No. 67/PMK.011/2010 untuk menjamin pasokan bahan baku biji kakao. Hasil dilaksanakannya program Gernas Kakao dan diberlakukannya BK tersebut menunjukkan bahwa volume ekspor kakao dalam bentuk biji terus menurun dan sebaliknya volume ekspor produk olahan kakao terus meningkat. Dampak kebijakan tersebut akan semakin nyata dalam pengembangan agribisnis kakao bila dilakukan melalui perumusan kebijakan yang harmonis dan sinergis antara aspek budidaya kakao (sektor hulu) dan industri pengolahan kakao (sektor hilir).

Kata kunci: budidaya kakao, pengolahan, agribisnis kakao, kebijakan industri
\end{abstract}

\section{PENDAHULUAN}

\section{A. Latar Belakang}

Kakao merupakan salah satu komoditas unggulan penting Indonesia yang merupakan sumber penghidupan bagi sekitar 1,4 juta rumah tangga. Secara nasional, perkebunan kakao memberikan kontribusi ekspor keempat terbesar setelah sawit, karet, dan kopi. Tahun 2013, luas perkebunan kakao Indonesia mencapai 1,74 juta ha dengan volume produksi 720.862 ton biji kakao diperkirakan 95 persen perkebunan kakao dikelola oleh rakyat. Dari jumlah ini sebesar 414.092 ton atau sekitar 57,4 persen diekspor dengan nilai ekspor sekitar USD1,15 miliar (Kementerian Pertanian, 2015). Komoditas ini dikembangkan mengingat peranannya dalam mendukung perekonomian nasional yang sangat penting. Lebih lanjut prospek pengembangan komoditas kakao ini sangat cerah, hal ini diungkapkan oleh Ketua Umum Dewan Kakao Indonesia, Soetanto Abdoellah bahwa pada tahun 2020 diprediksi akan 
terjadi defisit pasokan kakao global mencapai satu juta ton (www.btcocoa.com, 2014).

Dari sisi potensi sumber daya alam, Indonesia memiliki lahan yang sangat potensial untuk pengembangan budidaya kakao, yaitu lebih dari 6,2 juta ha terutama di Sulawesi. Di samping itu pada saat ini kebun yang sudah ada masih berpeluang untuk ditingkatkan produktivitasnya karena produktivitas rata-rata saat ini masih kurang dari separuh potensinya. Disisi lain situasi perdagangan kakao dunia beberapa tahun terakhir sering mengalami defisit, sehingga berdampak pada harga kakao dunia yang relatif stabil pada tingkat yang tinggi. Kondisi ini merupakan suatu peluang yang memiliki prospek cerah untuk secepatnya komoditas kakao dikembangkan guna meningkatkan kesejahteraan masyarakat.

Dalam kurun satu dasawarsa terakhir ini meskipun luas areal perkebunan kakao terus meningkat dengan rata-rata peningkatan sekitar 7,9 persen per tahun, dan peningkatan produksinya rata-rata mencapai 7,2 persen per tahun ternyata tingkat produktivitasnya cenderung menurun dengan rata-rata sekitar 0,7 persen per tahun (Murniningtyas, 2011). Dengan kenyataan itu pemerintah melalui Kementerian Pertanian telah melakukan upaya untuk meningkatkan produktivitas kakao melalui pelaksanaan Program Revitalisasi Perkebunan sejak tahun 2007 yang selanjutnya lebih diperkuat lagi melalui Program Gernas Kakao sejak tahun 2009.

Program Gernas kakao ini mulai dilaksanakan padatahun 2009 mencakup areal lahan seluas 450.000 ha dari seluruh luas lahan kakao nasional sebesar 1,65 juta ha yang terdiri atas tiga kegiatan utama, yaitu (a) peremajaan, yang dilakukan mengingat bahwa ratarata tanaman kakao di Indonesia sudah berumur tua sehingga tidak produktif lagi. Peremajaan ini dilakukan melalui penggantian tanaman kakao yang tua/tidak produktif lagi dengan menggunakan bibit unggul yang berasal dari teknik perbanyakan/kloning Somatic Embryogenesis (SE), dengan target seluas 70.000 ha, (b) rehabilitasi, yang dilakukan mengingat bahwa rata-rata tanaman kakao di Indonesia masih sangat rendah produktivitasnya sehingga perlu perbaikan genetik tanaman melalui penerapan teknik Sambung Samping, dengan target seluas 235.000 ha, dan (c) intensifikasi, yang dilakukan mengingat bahwa rata-rata kebun kakao rakyat tidak dibudidayakan secara intensif sehingga perlu dilakukan budidaya secara intensif sesuai dengan prosedur oparasional standar (standard operational procedure) dengan target seluas 145.000 ha (Barani, 2011).

Pemerintah menargetkan bahwa pada tahun 2020 luas areal lahan kakao mencapai sekitar 2 juta ha. Dengan dilaksanakannya program Gernas Kakao ini diharapkan produktivitas kakao meningkat.
Dengan perhitungan bahwa rata-rata produksi kakao sebesar 0,6 ton/ha/tahun maka produksi kakao nasional akan mencapai kurang lebih sebesar 1,2 juta ton sehingga diharapkan akan menjadi produsen kakao terbesar di dunia (Antoni, 2015). Melimpahnya produksi yang disertai dengan meningkatnya mutu biji kakao nasional diharapkan tidak langsung diekspor dalam bentuk biji. Produksi biji kakao ini harus diatur sedemikain rupa sehingga dapat diolah oleh industri pengolahan kakao dalam negeri.

Pengolahan biji kakao yang dilakukan di Indonesia ini bertujuan agar nilai tambah komoditas kakao dapat dinikmati oleh masyarakat. Pada saat ini diperkirakan sekitar 84 persen produksi kakao nasional diekspor dalam bentuk biji kakao mentah sedangkan sisanya sebesar 16 persen diolah di dalam negeri dalam bentuk cocoa powder dan cocoa butter yang memiliki nilai jual yang tinggi (Kementerian Koordinator Perekonomian Republik Indonesia, 2010). Hal ini disebabkan karena industri pengolahan kakao masih mengalami kesulitan untuk memperoleh pasokan bahan baku berupa biji kakao dalam jumlah maupun kualitas yang memadai. Meskipun saat ini industri pengolahan kakao sudah mulai bermunculan namun masih belum optimal karena industri pengolahan kakao di Indonesia masih beroperasi jauh di bawah kapasitas produksinya. Badan Kebijakan Fiskal, Kementerian Keuangan melansir data bahwa pada tahun 2011 total kapasitas terpasang industri pengolahan kakao di Indonesia mencapai sebesar 469.000 ton, namun kapasitas terpakainya hanya 280.000 ton atau hanya 59,7 persen (Kementerian Keuangan, 2012).

Agar industri pengolahan kakao dapat berkembang di Indonesia dengan mendapatkan jaminan pasokan bahan baku biji kakao maka pemerintah harus membuat beberapa kebijakan yang mengatur tata niaga sehingga arus ekspor dalam bentuk biji kakao dibatasi. Upaya pemerintah untuk membatasi arus ekspor biji kakao ini dilakukan melalui kebijakan pengenaan Bea Keluar (BK) ekspor biji kakao. Kebijakan ini telah diatur dalam Peraturan Menteri Keuangan (PMK) No. 67/PMK.011/2010 yang kemudian diperbarui dengan PMK No. 75/ PMK.011/2012 beserta kebijakan-kebijakan lain terkait dengan pemberian kemudahan dalam pengembangan industri pengolahan kakao. Dalam Peraturan Menteri Keuangan tersebut penetapan besarnya BK ini adalah sebagai berikut: (a) pada tingkat harga biji kakao di bawah USD2.000/ton maka tidak dikenakan BK sama sekali, (b) pada kisaran harga antara USD2.0002.750/ton dikenakan BK sebesar 5 persen, (c) pada kisaran harga antara USD2.750-3.500/ton dikenakan BK sebesar 10 persen, dan (d) pada tingkat harga lebih dari USD3.500/ton dikenakan BK sebesar 15 persen. 
Pemberlakuan BK ekspor biji kakao ini merupakan sarana yang ampuh untuk menjamin pasokan bahan baku industri kakao nasional bahkan diharapkan akan mendorong tumbuhnya industri pengolahan kakao yang baru. Dampak dikenakannya BK tersebut maka nilai ekspor kakao dalam bentuk biji terus menurun dan sebaliknya ekspor olahan kakao, seperti cocoa powder, cocoa butter, cocoa paste maupun chocolate terus meningkat. Nilai ekspor biji kakao pada tahun 2008 mencapai USD854,58 juta dan pada tahun 2012 turun menjadi USD384,83. Sebaliknya nilai ekspor olahan kakao pada tahun 2008 hanya sebesar USD116,72 juta dan pada tahun 2012 meningkat menjadi USD176,89 (Haifan, 2015). Tumbuhnya industri pengolahan ini diharapkan pula akan meningkatkan efek pengganda (multiplier effects) yaitu menyerap tenaga kerja Indonesia dan menggerakkan sektor-sektor lain yang terkait, seperti transportasi, perdagangan, jasa, dan lain-lain.

Dalam upaya pengembangan agribisnis kakao nasional perlu dilakukan perumusan maupun penyempurnaan kebijakan yang harmonis, terintegrasi, dan sinergis antara aspek budidaya (sektor hulu) dan industri pengolahan kakao (sektor hilir). Melalui dukungan harmonisasi kebijakan hulu-hilir ini diharapkan akan menciptakan iklim usaha/investasi yang kondusif bagi berkembangnya agribisnis kakao nasional. Lebih lanjut, dukungan dari aspek kebijakan ini diharapkan akan bermuara dalam meningkatkan produktivitas, kualitas dan kontinuitas produksi kakao dan meningkatkan volume dan kualitas produksi dari industri pengolahan kakao dalam negeri yang akan mampu bersaing di pasar global. Tanpa adanya harmonisasi kebijakan hulu-hilir ini maka harapan untuk mencapai target sebagai negara pengekspor utama produk olahan kakao dunia kemungkinan besar tidak akan tercapai.

\section{B. Permasalahan}

Meskipun Indonesia memiliki potensi sumber daya alam yang memadai untuk budidaya kakao dan prospek pengembangan komoditas kakao yang cerah, masih ada berbagai permasalahan yang dihadapi baik dari aspek budidayanya maupun dari aspek industri pengolahannya. Pada tahun 2003 tingkat produktivitas kakao rata-rata mencapai $1.060 \mathrm{~kg} / \mathrm{ha} / \mathrm{tahun}$ dan berangsur turun hingga pada tahun 2008 yang hanya mencapai 779 kg/ha/tahun. Bahkan pada tahun 2009 terjadi penurunan tingkat produktivitas yang lebih parah lagi hanya mencapai $660 \mathrm{~kg} / \mathrm{ha} /$ tahun (Barani, 2011). Menurut data dari Direktorat Jenderal Perkebunan menunjukkan bahwa pada tahun 2013 rata-rata tingkat produktivitas kakao di Indonesia hanya mencapai $414 \mathrm{~kg} / \mathrm{ha} /$ tahun (Kementerian Pertanian, 2015). Tingkat produktivitas ini sangat jauh di bawah rata-rata ideal yang mencapai $2.000 \mathrm{~kg} / \mathrm{ha} /$ tahun. Terjadinya penurunan produksi ini disebabkan karena (a) masih banyak tanaman kakao di Indonesia sudah berumur tua lebih dari 20 tahun sehingga tidak produktif lagi, (b) banyak tanaman kakao di Indonesia yang terserang berat hama dan penyakit tanaman maupun jenis tanaman kakao yang kurang unggul sehingga ratarata produktivitasnya masih sangat rendah, (c) banyak kebun kakao rakyat yang tidak dibudidayakan secara intensif karena tingkat keuntungan dalam budidaya kakao masih sangat rendah sehingga petani tidak mempunyai modal yang cukup untuk menyediakan sarana produksi yang memadai. Bila diperhitungkan dengan ekspor kakao secara keseluruhan, jumlah kerugian yang diakibatkan oleh penurunan prduktivitas dan mutu kakao nasional mencapai Rp4,05 triliun per tahun. Di samping itu, rendahnya mutu kakao tersebut menyebabkan citra kakao Indonesia menjadi kurang baik di pasar internasional (Barani, 2011). Adanya permasalahan ini mengakibatkan sampai saat ini belum bisa bersaing dengan produsen utama kakao dunia, yaitu Pantai Gading dan Ghana.

Industri pengolahan kakao saat ini masih mengalami masa kesulitan sehingga belum bisa berkembang optimal bahkan tertinggal dibandingkan negara-negara produsen produk olahan kakao yang tidak mempunyai kebun, seperti Singapura, terutama adalah Pertama, keterkaitan dalam memperoleh pasokan bahan baku berupa biji kakao dalam jumlah maupun kualitas yang memadai. Meskipun saat ini industri pengolahan kakao sudah mulai bermunculan namun masih belum optimal, diperkirakan industri pengolahan kakao masih beroperasi di bawah kapasitas produksinya. Sebagai contoh pada tahun 2010 PT Bumi Tangerang Mesindotama memiliki kapasitas terpasang 75.000 ton dan kapasitas terpakai hanya 45.000 ton (Haifan, 2015). Pada tahun 2011 Badan Kebijakan Fiskal, Kementerian Keuangan melansir data bahwa total kapasitas terpasang industri pengolahan kakao di Indonesia mencapai sebesar 469.000 ton namun kapasitas terpakainya hanya 280.000 ton atau hanya 59,7 persen (Kementerian Keuangan, 2012). Kedua, kualitas kakao nasional yang relatif masih rendah mengingat sebagian besar produksi biji kakao (sekitar 85 persen) belum dilakukan fermentasi sehingga sulit bersaing di pasar internasional.

Oleh karena itu kakao asal Indonesia yang diekspor ke negara-negara Uni Eropa dikenakan diskriminasi tarif dan mulai tahun 1991 untuk pasar ke Amerika Serikat mengalami automatic detention. Ini semua disebabkan karena kebijakan-kebijakan yang terkait dengan pengembangan budidaya kakao dan industri pengolahan kakao yang masih belum harmonis dan belum tepat, seperti kebijakan budidaya kakao yang berkelanjutan (sustainability), kebijakan sertifikasi kakao, kebijakan 


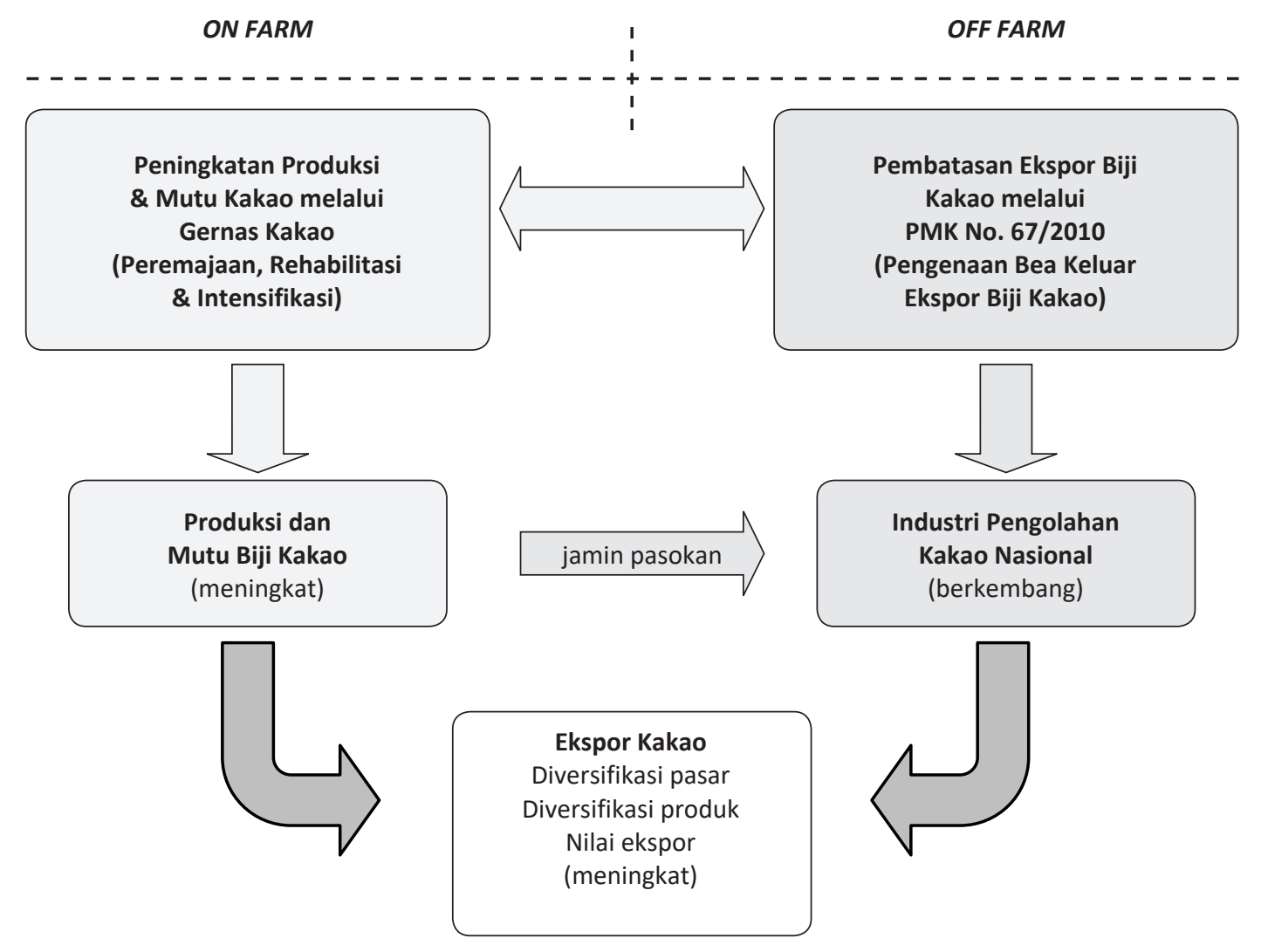

PMK = Peraturan Menteri Keuangan.

Sumber: Hasil analisis penulis.

Gambar 1. Kerangka Teori Harmonisasi Kebijakan dalam Pengembangan Budidaya dan Industri Pengolahan Kakao

fermentasi biji kakao, kebijakan peningkatan konsumsi cokelat, dan lain-lain. Karena itu, penguatan harmonisasi kebijakan hulu-hilir menjadi hal penting dilakukan.

\section{Tujuan}

Pengkajian ini bertujuan untuk memperoleh pemahaman yang lebih jelas terkait dengan upaya pengembangan agribisnis kakao nasional melalui harmonisasi dan sinkronisasi kebijakan huluhilir dalam pengembangan budidaya dan industri pengolahan kakao.

\section{KERANGKA TEORI}

Kerangka teori ini mendeskripsikan kebijakankebijakan terkait dengan pengembangan agribisnis kakao baik dari aspek budidaya maupun industri pengolahan yang saling bergantung dan berinteraksi. Dari aspek budidaya khususnya ditekankan pada upaya untuk meningkatkan produksi, produktivitas, dan mutu kakao dalam negeri. Sedangkan dari aspek industri pengolahan ditekankan pada upaya untuk meningkatkan volume produksi, daya saing (competitiveness), dan nilai tambah (value-added) usaha. Secara garis besar kerangka teori kebijakan pengembangan budidaya dan industri pengolahan kakao nasional dideskripsikan pada Gambar 1.
Dari Gambar 1 terlihat bahwa pemerintah terus berupaya untuk meningkatkan produksi dan mutu kakao Indonesia yang dilakukan pada tahun 2009 melalui program Gernas Kakao. Dampak dilaksanakannya program Gernas Kakao tersebut adalah meningkatnya produksi biji kakao yang cukup nyata. Agar nilai tambah maupun nilai ekspor kakao Indonesia bisa meningkat dan dinikmati oleh masyarakat Indonesia maka melimpahnya produksi biji kakao tersebut harus dikendalikan sedemikian rupa sehingga tidak langsung diekspor dalam bentuk biji. Produksi biji kakao ini harus diatur sedemikian rupa sehingga produksi biji kakao dapat diolah oleh industri pengolahan kakao dalam negeri. Beberapa kebijakan pemerintah yang terkait dengan upaya pengembangan industri pengolahan kakao antara lain adalah Peraturan Pemerintah (PP) No. 52/2011 yang kemudian direvisi dengan PP No. 18/2015 tentang Pembebasan Pajak/Tax Allowance. Meningkatnya produksi dan mutu biji kakao di satu pihak dan berkembangnya industri pengolahan kakao di lain pihak diharapkan akan meningkatkan diversifikasi pasar, diversifikasi produk, dan nilai ekspor hasil olahan kakao. Di samping itu, diharapkan industri pengolahan kakao dapat menerima pasokan bahan baku biji kakao dengan harga yang tinggi karena kualitasnya meningkat. Hal ini akan berdampak 
merangsang petani kakao dalam melaksanakan budidaya secara lebih intensif sehingga produktivitas dan kualitasnya semakin meningkat yang selanjutnya akan meningkatkan pendapatan petani. $\mathrm{Di}$ lain pihak dengan berkembangnya budidaya kakao ini diharapkan dapat memberi jaminan pasokan bahan baku dalam jumlah dan kualitas yang memadai. Hal ini akan berdampak merangsang berkembangnya industri pengolahan kakao di dalam negeri sehingga diharapkan akan meningkatkan nilai tambah (valueadded), daya saing (competitiveness), maupun efek pengganda (multiplier effects) yang dapat dinikmati oleh masyarakat/bangsa Indonesia.

Dengan demikian upaya pengembangan agribisnis kakao Indonesia tidak dapat berhasil dengan baik bila hanya dengan mendasarkan pada kebijakan-kebijakan yang dirumuskan secara sektoral. Kedua sektor, baik sektor pertanian yang terkait dengan aspek budidaya kakao dan sektor industri yang terkait dengan aspek industri pengolahan kakao sesungguhnya merupakan satu sistem sebagaimana dua sisi mata uang yang tidak bisa dipisahkan. Oleh karena itu, dalam perumusan kebijakannya harus dilakukan secara harmonis, terintegrasi, dan sinergis dalam satu sistem pengembangan agribisnis kakao nasional. Upaya peningkatan produksi dan mutu kakao nasional tidak akan berhasil dengan baik kalau tidak didukung oleh adanya industri pengolahan yang memadai. Demikian pula sebaliknya industri pengolahan kakao nasional tidak akan dapat berhasil dengan baik tanpa adanya jaminan pasokan bahan baku kakao dalam kuantitas, kualitas, dan kontinuitas yang memadai.

\section{METODOLOGI}

Penelitian ini merupakan kajian deskriptif analisis dengan menggunakan data dan informasi yang diperoleh melalui berbagai metode (a) observasi atau pengamatan lagsung di lokasi yang merupakan salah satu teknik pengumpulan informasi dan data untuk mengetahui keadaan yang sesungguhnya di lapangan, (b) wawancara terstruktur dengan informan kunci (key persons) yang terkait dengan penanganan dari aspek budidaya sampai dengan industri kakao nasional. Untuk menunjang pengumpulan data dan informasi dilakukan Focus Group Discussion (FGD) dengan mengundang beberapa pakar dari lembaga penelitian, perguruan tinggi, dan para pemangku kepentingan yang terkait.

Lokasi pelaksanaan pengumpulan informasi dan data primer terutama dilakukan di Provinsi Sulawesi Selatan yang merupakan sentra produksi kakao dan lokasi beberapa industri pengolahan kakao. Sedangkan pengumpulan data sekunder terutama dilakukan melalui penelahaan berbagai publikasi ilmiah atau jurnal maupun berbagai kebijakan yang tertuang dalam surat keputusan pemerintah terkait dalam pengembangan budidaya maupun industri pengolahan kakao.

Waktu penelitian dilakukan pada bulan April sampai dengan November 2013 dan untuk menunjang kegiatan pengumpulan data dan informasi dilakukan FGD di Jakarta pada tanggal 7 Mei 2013 untuk menjaring berbagai informasi dan data khususnya dari para pemangku kepentingan (stakeholder) terutama dari Kementerian Pertanian dan Kementerian Perindustrian.

Teknik analisis data dilakukan melalui (a) penelaahan/evaluasi dokumen-dokumen kebijakan yang dikeluarkan oleh pemerintah yang terkait dengan pengembangan kakao nasional dan (b) perumusan konsep untuk penyempurnaan kebijakan terutama terkait dengan upaya pemerintah untuk meningkatkan produktivitas maupun kualitas produksi kakao nasional dan meningkatkan volume produksi industri pengolahan kakao dalam negeri. Perumusan kebijakan yang berhubungan dengan harmonisasi dan sinkronisasi kebijakan hulu-hilir untuk meningkatkan nilai tambah, daya saing, maupun efek pengganda dalam pengembangan agribisnis kakao di Indonesia.

\section{HASIL DAN PEMBAHASAN}

\section{A. Hasil}

Dari aspek budidaya, kondisi perkebunan kakao di Indonesia saat ini masih sangat memprihatinkan di mana sejak tahun 2003 produksi kakao terus mengalami kecenderungan menurun. Terjadinya penurunan tingkat produktivitas kakao ini terutama disebabkan karena umur tanaman kakao yang sudah tua, kondisi tanaman yang rusak/tidak terawat juga karena terjadinya serangan hama/organisme pengganggu tanaman dan penyakit kakao seperti pembuluh kayu kakao atau Vascular Streak Dieback (VSD). Pada Gambar 2 terlihat kondisi kebun kakao yang tua/rusak dan Gambar 3 terlihat kondisi kebun kakao yang terlantar/kurang produktif.

Berkaitan dengan kondisi budidaya kakao saat ini yang masih belum optimal maka pemerintah diharapkan untuk terus merumuskan berbagai kebijakan terutama dalam bidang budidaya untuk memacu peningkatan

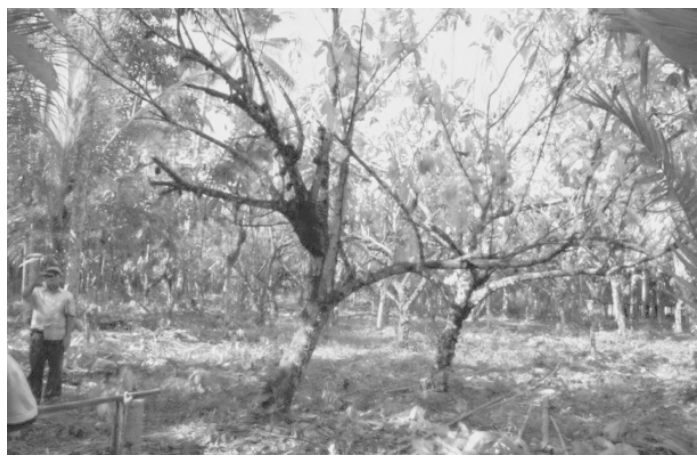

Gambar 2. Kondisi Kebun Kakao yang Tua/Rusak 


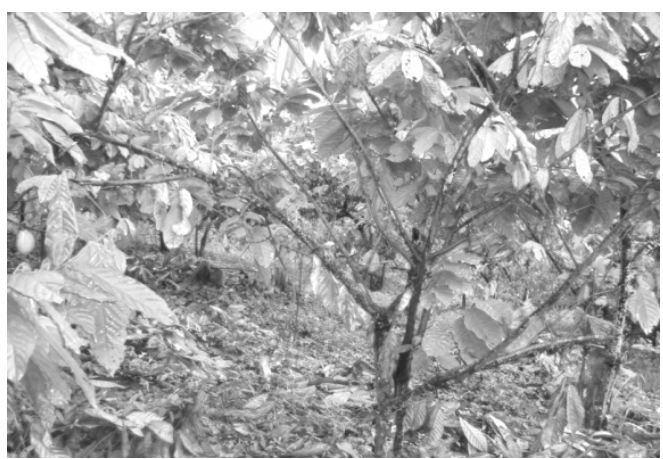

Gambar 3. Kondisi Kebun Kakao yang Kurang Produktif

produksi dan kualitas kakao. Hal ini terkait dengan industri pengolahan kakao yang membutuhkan adanya jaminan volume pasokan bahan baku yang memadai dan kualitas biji kakao yang tinggi. Di samping itu pada tahun 2020 kakao yang diekspor ke Uni Eropa maupun Amerika, baik dalam bentuk biji maupun hasil olahan kakao diwajibkan memiliki sertifikasi yang berasal dari budidaya kakao berkelanjutan (sustainability). Prinsip budidaya kakao yang berkelanjutan meliputi tiga kriteria utama, yakni mengikuti kaidah-kaidah ekonomi, sosial-budaya, dan lingkungan termasuk dalam hal ini adalah praktek budidaya yang baik (Good Agricultural Practices atau GAP) dan konservasi sumber daya alam. Dalam pasar kakao global, konsumen tidak hanya menginginkan kualitas kakao yang tinggi tetapi juga dihasilkan dari proses yang beraspek ekonomi, sosialbudaya, dan lingkungan yang baik sehingga menjamin keberlanjutan usaha.

Sebagai gambaran sampai saat ini kakao yang diproduksi di Indonesia masih banyak yang berkualitas rendah karena serangan hama dan penyakit. Hal ini berdampak terhadap harga ekspor biji kakao ke Amerika Serikat yang mengalami penurunan sebesar USD301,5 per ton. Bila jumlah ekspor biji kakao ke Amerika Serikat rata-rata mencapai 130.000 ton per tahun, maka terdapat potensi kehilangan devisa sebesar USD39,19 juta per tahun. Bila diperhitungkan dengan ekspor kakao secara keseluruhan, jumlah kerugian yang diakibatkan oleh penurunan prduktivitas dan mutu kakao nasional mencapai Rp4,05 triliun per tahun.

Dalam industri pengolahan kakao, sebelum diproses bahan baku biji kakao ini harus difermentasi terlebih dahulu untuk memenuhi selera konsumen. Fermentasi merupakan inti dari proses pengolahan biji kakao di mana merupakan proses pembentukan cita rasa khas kakao dengan bantuan mikroba alami agar diperoleh mutu biji kakao yang baik. Sampai saat ini produksi kakao nasional sebagian besar meliputi kurang lebih 95 persen adalah merupakan hasil kebun kakao petani, di mana sebagian besar petani kakao masih enggan melakukan fermentasi.
Menurut data dari Pusat Penelitian Kopi dan Kakao menunjukkan bahwa lebih dari 85 persen kakao nasional masih belum difermentasi (Komisi Pengawas Persaingan Usaha Republik Indonesia, 2009). Lebih lanjut dari hasil kajian melalui Constant Market Share Analysis (CMSA) yang dilakukan oleh Institut Pertanian Bogor (IPB) menunjukkan bahwa produk-produk kakao yang memiliki daya saing adalah produk-produk kakao olahan (Hasibuan, et al., 2012). Hal ini merupakan tantangan yang harus dihadapi untuk meningkatkan industri pengolahan kakao termasuk pemasyarakatan konsumsi kakao yang diharapkan akan berdampak dalam penyerapan tenaga kerja dan nilai tambah usaha.

\section{B. Pembahasan}

\section{Kebijakan Pengembangan Budidaya Kakao}

Beberapa kebijakan utama dalam pengembangan budidaya kakao yang perlu dirumuskan untuk meningkatkan produktivitas dan mutu kakao sehingga menjadi jaminan untuk memasok bahan baku yang memadai dalam pengembangan industri pengolahan kakao adalah:

\section{a. Penyediaan Bibit Kakao Unggul}

Tersedianya bibit unggul kakao merupakan suatu hal yang mutlak diperlukan untuk peremajaan tanaman sebagai upaya peningkatan produksi, produktivitas, dan mutu kakao. Secara teknis tanaman kakao unggul memiliki kriteria sebagai berikut: memiliki daya hasil tinggi ( $>2$ ton/ha/tahun), jumlah biji per tongkol ratarata $>30$, berat per biji kering $=1 \mathrm{~g}$, rendemen (nisbah biji kering terhadap biji segar berlendir) $>30$ persen, kadar lemak > 50 persen, kadar kulit ari < 12 persen, untuk kakao mulia mempunyai sifat biji segar berwarna putih > 90 persen. Tahan terhadap serangan hama dan penyakit utama, antara lain hama penghisap tunas dan buah (Helopeltis spp.), hama Penggerek Buah Kakao (PBK) dan penyakit busuk buah (Phytophtora palmivora). Adapun klon kakao unggul generasi ketiga yang dihasilkan sesudah tahun 1998, yaitu ICCRI 01 (2.510 kg/ha/tahun), ICCRI 02 (2.340 kg/ha/tahun), ICCRI 03 (2.090 kg/ha/tahun), ICCRI 04 (2.060 kg/ha/ tahun) (Fahmi, 2011).

Dari hasil evaluasi pelaksanaan Gernas Kakao yang dilakukan oleh peneliti dari Pusat Penelitian dan Pengembangan Sumber Daya Alam, Universitas Hasanuddin pada tahun 2012 dengan lokasi penelitian di Provinsi Sulawesi Selatan dan Sulawesi Barat menunjukkan bahwa performa tanaman kakao yang berasal dari teknik Somatic Embryogenesis (SE) ini kurang berhasil dengan baik. Tanaman kakao sebanyak 74 persen yang berasal dari perbanyakan kloning SE yang ditanam pada tahun 2009 dan 2011 untuk peremajaan memiliki struktur dan perkembangan 
akarnya yang kurang mampu mendukung tumbuhnya tanaman sehingga menyebabkan tanaman menjadi mudah rebah terkena hembusan angin. Sebanyak 68 persen tanaman dari hasil perbanyakan SE ini yang diklaim sebagai tanaman yang tahan terhadap serangan penyakit VSD ternyata terserang penyakit VSD dan hama-penyakit lainnya (Gusli, 2012). Namun, di samping adanya kelemahan tersebut, bibit tanaman kakao yang berasal dari teknik SE ini memiliki sifat unggul yang sama dengan tanaman induknya yang berproduktivitas tinggi sehingga lebih baik dibandingkan dengan pembibitan yang dilakukan secara konvensional (Limbongan \& Djufry, 2013).

Terkait dengan teknik pembibitan ini, beberapa petani penangkar bibit tanaman kakao di Kabupaten Luwu dan Luwu Utara, Sulawesi Selatan lebih memilih menggunakan teknik Sambung Pucuk karena teknologinya sederhana dan sudah dikenal oleh petani setempat, mudah diterapkan, bahan yang digunakan mudah diperoleh, dan tingkat keberhasilannya tinggi (Limbongan \& Djufry, 2013). Lebih lanjut beberapa keunggulan bibit tanaman kakao yang diperoleh dengan teknik Sambung Pucuk ini antara lain adalah jauh lebih cepat berbuah dibanding dengan menggunakan bibit SE di mana hanya membutuhkan waktu sekitar satu setengah tahun untuk bisa mulai memanen kakao. Melihat kenyataan ini Pemerintah Provinsi Sulawesi Selatan melalui Dinas Perkebunan pada tahun 2012 telah mengusulkan penghentian pengembangan bibit kakao yang berasal dari teknik SE ini kepada pemerintah pusat dalam program peremajaan tanaman kakao di Sulawesi Selatan. Pemerintah Provinsi Sulawesi Selatan merencanakan pengembangan bibit kakao untuk peremajaan dengan menggunakan teknik Sambung Pucuk ini dalam upaya meningkatkan produktivitas kakao di mana beberapa tahun terakhir ini telah dilakukan meliputi luas 106.000 ha (www.industri.bisnis.com., 2012).

Lebih lanjut, terkait dengan upaya rehabilitasi tanaman kakao yang kurang produktif dibutuhkan penyediaan entres bibit kakao unggul yang bersertifikat. Hal ini mengingat bahwa masih banyak kebun petani kakao diluar program Gernas Kakaoyang produktivitasnya rendah memerlukan rehabilitasi dengan menggunakan entres yang dihasilkan dari kebun entres kakao. Dari hasil diskusi dengan beberapa pemerhati dan pengamat kakao di Provinsi Sulawesi Selatan mengindikasikan bahwa pada saat ini diperlukan dalam jumlah yang besar entres bibit unggul kakao yang bersertifikat. Entres ini sangat dibutuhkan petani untuk melakukan rehabilitasi kebun kakao dengan cara Sambung Samping untuk meningkatkan produktivitasnya. Dalam hal ini bahan tanaman berupa entres yang unggul dan bersertifikat untuk rehabilitasi tanaman kakao akan mampu berproduksi sebesar 2 ton/ha/tahun (Rubiyo \& Siswanto. 2012). Pemerintah melalui Kementerian Pertanian menyatakan bahwa salah satu faktor penentu keberhasilan pengembangan kakao adalah adanya dukungan ketersediaan bahan tanaman unggul. Bentuk dukungan yang dilakukan oleh Kementerian Pertanian adalah dengan diterbitkannya Peraturan Menteri Pertanian No. 09/Permentan/OT.140/1/2013 tentang Pedoman Teknis Pembangunan Kebun Induk dan Kebun Entres Kakao.

Dalam Peraturan Menteri Pertanian tersebut disebutkan berbagai klon kakao unggul yang dianjurkan sebagai entres kakao. Pada dasarnya ada dua jenis kakao unggul, yaitu Kakao Mulia dan Kakao Lindak. Klon-klon anjuran ini merupakan klon kakao lama hasil pengembangan generasi awal di mana klon-klon tersebut sebagian ada yang dimanfaatkan sebagai tetua kebun benih hibrida. Pada saat ini pertimbangan utama dalam memilih klon unggul antara lain adalah pertimbangan sifat unggul dari ketahanan terhadap Organisme Pengganggu Tanaman (OPT) utama yaitu hama Penggerek Buah Kakao (PBK), penyakit busuk buah, dan penyakit VSD.

Di Sulawesi Selatan saat ini mayoritas ada empat klon kakao unggul yang dibudidayakan petani, yaitu Sulawesi 01, Sulawesi 02, ICCRI 03, dan ICCRI 04. Klon ICCRI ini terutama ICCRI 03 merupakan klon kakao yang tahan terhadap penyakit busuk buah yang disebabkan oleh serangan Phytophtora palmivora (Ribiyo, et al., 2010). Khususnya Klon Kakao Sulawesi 01 dan Sulawesi 02 bukan hanya dikembangkan petani kakao yang ada di Sulawesi tetapi juga telah digunakan oleh petani kakao di seluruh Indonesia. Kedua klon kakao ini telah mendapatkan sertifikasi dari Pemerintah Indonesia tahun 2008. Pada Tabel 1 beberapa klon yang dianjurkan sebagai entres kakao di Indonesia beserta karakteristiknya.

Menurut petani kakao di Sulawesi Selatan, Klon Sulawesi 02 ini agak bandel di mana buahnya bisa mencapai lebih dari 40 buah per pohon, lebih banyak dibandingkan dengan Klon Sulawesi 01 dan umur masaknya lebih cepat. Lebih lanjut, berdasarkan data yang dipublikasikan oleh PT Mars Symbio Science menunjukkan bahwa potensi produksi kakao untuk Klon Sulawesi 01 bisa mencapai 1,8-2,5 ton/ha pada tahun ke 5 dengan kadar lemak 53 persen. Sedangkan Klon Sulawesi 02 potensi produksi buahnya bisa mencapai 1,8-2,7 ton/ha pada tahun ke-5 dengan kadar lemak 45-47 persen. Klon Kakao Sulawesi 01 dan Sulawesi 02 terbukti cepat berproduksi tinggi dan tahan terhadap serangan hama dan penyakit. Berikut ini Gambar 4 adalah tanaman Klon Kakao Sulawesi 01 dan Gambar 5 adalah tanaman Klon Kakao Sulawesi 02

Mengingat bahwa sebaran kebun kakao di Indonesia mencakup mulai dari pulau Sumatera 
Tabel 1. Keunggulan Beberapa Klon Kakao Unggul Indonesia yang Dilepas Melalui SK Menteri Pertanian Tahun 2005-2012

\begin{tabular}{cccl}
\hline No. & Klon Kakao & $\begin{array}{c}\text { Daya Hasil } \\
\text { (kg/ha/th) }\end{array}$ & $\begin{array}{c}\text { Kriteria Keunggulan / } \\
\text { Keterangan }\end{array}$ \\
\hline A. & Kakao Mulia & & \\
\hline 1. & ICCRI 01 & 2.370 & $\begin{array}{l}\text { Penghasil biji putih, tahan } \\
\text { penyakit busuk buah } \\
\text { SK Mentan No. 212/Kpts/ } \\
\text { SR.120/5/2005 }\end{array}$ \\
\hline 2. & ICCRI 02 & 2.500 & $\begin{array}{l}\text { Penghasil biji putih, tahan } \\
\text { penyakit busuk buah } \\
\text { SK Mentan No. 213/Kpts/ } \\
\text { SR.120/5/2005 }\end{array}$ \\
& & & $\begin{array}{l}\text { Penghasil biji putih, } \\
\text { tahan penyakit VSD } \\
\text { SK Mentan No. 1985/ } \\
\text { Kpts/SR.120/4/2009 }\end{array}$ \\
\hline 3. & ICCRI 05 & 1,540 & \\
& & &
\end{tabular}

\begin{tabular}{cccl}
\hline B. & Kakao Lindak & & \\
\hline 1. & Sulawesi 01 & 2.500 & $\begin{array}{l}\text { Produksi tinggi, tahan VSD } \\
\text { SK Mentan No. 694/Kpts/ } \\
\text { SR.120/12/2008 }\end{array}$ \\
\hline 2. & Sulawesi 02 & 2.750 & $\begin{array}{l}\text { Produksi tinggi, tahan VSD } \\
\text { SK Mentan No. 695/Kpts/ } \\
\end{array}$ \\
& & SR.120/12/2008 \\
\hline
\end{tabular}

\begin{tabular}{|c|c|c|c|}
\hline 3. & Sulawesi 03 & 1.837 & $\begin{array}{l}\text { Tahan hama PBK } \\
\text { SK Mentan No. } 2795 / \\
\text { Kpts/SR.120/8/2012 }\end{array}$ \\
\hline 4. & Scavina 6 & 1.540 & $\begin{array}{l}\text { Tahan penyakit VSD } \\
\text { SK Mentan No. 1984/ } \\
\text { Kpts/SR.120/4/2009 }\end{array}$ \\
\hline 5. & ICCRI 03 & 2.090 & $\begin{array}{l}\text { Produksi tinggi, tahan } \\
\text { penyakit busuk buah } \\
\text { SK Mentan No. 530/Kpts/ } \\
\text { SR.120/9/2006 }\end{array}$ \\
\hline
\end{tabular}

$\begin{array}{ll}\text { 6. ICCRI 04 2.060 } & \text { Produksi tinggi, tahan } \\ & \text { penyakit busuk buah } \\ & \text { SK Mentan No. 529/Kpts/ } \\ & \text { SR.120/9/2006 }\end{array}$

Sumber: Peraturan Menteri Pertanian No. 09/Permentan/OT.140/1/2013 tentang Pedoman Teknis Pembangunan Kebun Induk dan Kebun Entres Kakao.

sampai Papua maka akan sangat sulit kalau penyediaan entres kakao dipasok dari Pusat Penelitian Kopi dan Kakao yang ada di Jember, Jawa Timur. Apalagi petani kakao yang ada di pelosok-pelosok daerah praktis tidak memiliki akses untuk bisa mendapatkan entres kakao bila penyediaannya dilakukan secara terpusat. Oleh karena itu, perlu adanya kebijakan dari pemerintah provinsi, khususnya Dinas Perkebunan setempat, untuk melakukan pembinaan petani yang saat ini telah berprofesi sebagai penangkar bibit atau penyedia entres kakao di daerah-daerah.

Penyediaan entres kakao harus dilakukan sesuai dengan Standard Operasional Prosedur (SOP)

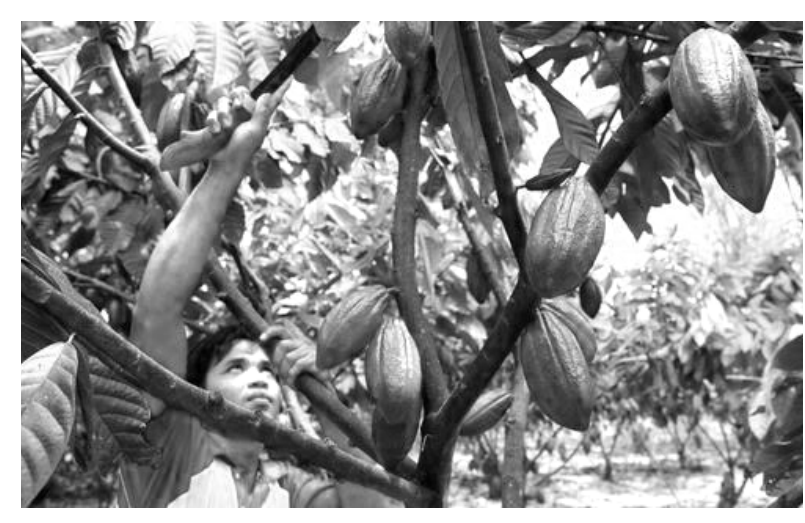

Gambar 4. Klon Kakao Sulawesi 01

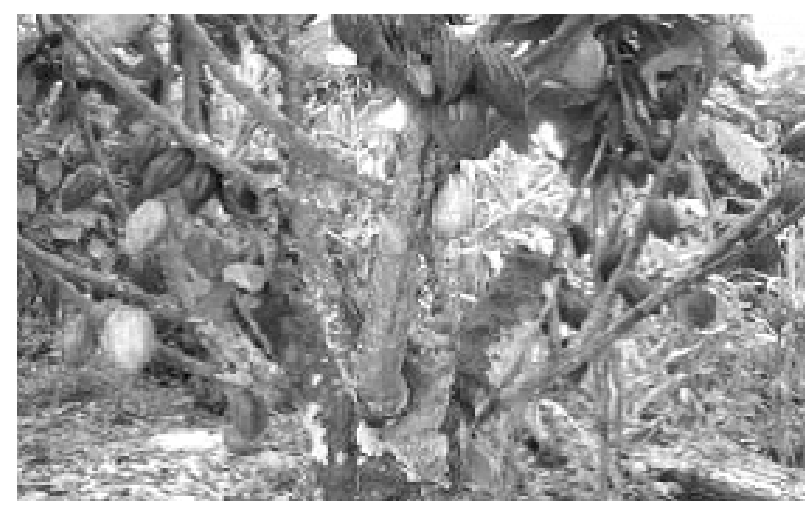

Gambar 5. Klon Kakao Sulawesi 02

sehingga benar-benar dapat dihasilkan entres yang berkualitas unggul sesuai dengan harapan. Hal penting yang perlu dilakukan adalah pembinaan terhadap petani sebagai penangkar bibit atau penyedia entres seyogyanya tersebar merata di daerah-daerah yang merupakan sentra produksi kakao sehingga para petani kakao yang banyak bermukim di daerah-daerah terpencil dapat dengan mudah memperoleh entres kakao unggul dalam upaya peningkatan produksi dan pengembangan agribisnis kakao.

\section{b. Kebijakan Sertifikasi Kakao}

Prospek pengembangan komoditas kakao sangat cerah karena ke depan masih terbuka lebar antara lain dengan meningkatnya permintaan kakao dunia, seperti dari negara-negara Uni Eropa (UE) maupun Amerika Serikat dan belum lama ini telah terjalin lagi pasar kakao yang baru, yaitu ekspor ke China, Rusia, India, Jepang, dan Timur Tengah. Oleh karena itu, Indonesia perlu mengantisipasi tuntutan konsumen kakao di pasar global di mana pada tahun 2020 bagi setiap hasil kakao yang diekspor ke negara-negara buyer di Uni Eropa maupun Amerika diwajibkan memenuhi persyaratan Sustainability dan Traceability. Oleh karena itu, sertifikasi ini amat penting terutama bagi Indonesia sebagai penghasil kakao nomor tiga dunia yang pada tahun 2013 memproduksi 720.862 ton kakao dan 
mengekspor 414.092 ton dengan nilai USD1,15 miliar (Kementerian Pertanian, 2015). Sertifikasi kakao yang dilakukan harus mengikuti kriteria-kriteria standar internasional sehingga produsen yang telah mengantongi sertifikat ini berhak untuk mendapatkan harga kakao yang tinggi. Sustainability dinyatakan dalam bentuk pengakuan berupa sertifikat yang dikeluarkan untuk menunjukkan bahwa rantai pasokan telah mengikuti aturan-aturan yang berlaku. Komoditas kakao yang telah memiliki sertifikat Sustainability ini memiliki beberapa keuntungan, antara lain adalah pemasaran yang lebih mudah, harga kakao yang wajar/ tinggi, dan pertanian yang berkelanjutan meliputi dipenuhinya dari aspek sosial, lingkungan, ekonomi, adanya program pelatihan bagi petani, dan lain-lain.

Bahkan ke depan konsumen kakao dunia khususnya dari beberapa negara maju menuntut adanya komoditas kakao yang tidak hanya memenuhi persyaratan Sustainability tetapi juga Traceability. Munculnya tuntutan yang dinamis terhadap persyaratan komoditas kakao ini mendorong pemerintah untuk mengantisipasi sesegera mungkin melalui adopsi sistem operasional yang senantiasa memperhatikan persyaratan-persyaratan Sustainability dan Traceability. Traceability adalah rekam jejak mengenai asal muasal kakao ini. Aturan itu menyangkut adanya berbagai uji terhadap kakao, antara lain adalah uji asal usul kakao ini diproduksi. Sebuah produk pangan dinyatakan baik jika produk tersebut dapat dilacak asal usulnya sejak mulai pelaksanaan budidaya, panen, pasca panen sampai ke konsumen. Penerapan aturan mengenai traceability ini dilakukan terutama terkait dengan persoalan keamanan pangan bagi konsumen kakao, di samping sebagai argumentasi untuk mencegah cara-cara budidaya kakao yang tidak mengindahkan aspek lingkungan sehingga dihasilkan kakao yang benar-benar berkualitas prima dan menjamin keberlanjutan usaha.

Standar ukuran untuk bisa memperoleh sertifikasi kakao ini harus memenuhi beberapa hal penting, seperti memperhatikan regenerasi budidaya komoditas, keamanan petani saat menyemprotkan pestisida, tidak menggunakan bahan-bahan kimia atau kayu bakar dari hutan lindung, dan petani tidak boleh mempekerjakan anak di bawah umur, dan lain-lain. Sertifikasi ini dipandang penting untuk mendongkrak citra kakao Indonesia yang selama ini dinilai kualitas buruk di mata internasional. Ekspor biji kakao ke Amerika Serikat sudah lama terkena Automatic detention atau potongan harga yang besarnya antara USD90-150 per ton karena kualitas biji kakao rendah (Manurung, 2012). Melalui sertifikasi ini diharapkan tidak banyak menambah biaya tetapi dapat meningkatkan kuantitas dan kualitas produksi kakao yang lebih nyata sehingga dapat bersaing dengan produsen kakao lain untuk mendapatkan harga premium di pasar internasional.
Pada saat ini perusahaan sertifikasi internasional seperti UTZ Certified dan Rainforest Alliance bekerja sama dengan Kementerian Pertanian telah menetapkan berbagai kriteria untuk sertifikasi kakao yang mencakup mulai dari bibit, penyiapan lahan hingga pengolahan biji kakao. Pemerintah perlu merumuskan kebijakan yang mewajibkan penggunaan bibit unggul kakao yang bersertifikat. Pada tahap awal yang merupakan lokasi percontohan pelaksanaan sertifikasi kakao di Indonesia diharapkan dapat dimulai di daerah-daerah yang merupakan sentra produsen kakao yang meliputi delapan provinsi dengan volume total $40.000 \mathrm{MT}$ sebagai berikut (Wijaya, 2011).

Selain itu terkait dengan upaya untuk menjamin keberlanjutan usaha, pada tahun 2011, PT Nestle menyelenggarakan Lokakarya Pengembangan Kakao Berkelanjutan di Makassar. Pemerintah Indonesia perlu mendukung pelaksanaan sertifikasi ini di mana embrionya telah dimulai oleh Kementerian Pertanian yang saat ini tengah menyusun program Kakao Berkelanjutan Indonesia atau Indonesian Sustainable Cocoa (ISC) yang merupakan panduan dalam pengembangan komoditas kakao berkelanjutan di Indonesia.

\section{c. Kebijakan Penguatan Kelembagaan Forum Cocoa Sustainability Partnership (CSP)}

Menyadari akan berbagai permasalahan yang dihadapi dalam upaya pengembangan kakao nasional, pada tanggal 23 Januari 2006 beberapa pemangku kepentingan yang terkait dengan komoditas kakao, seperti Asosiasi Kakao Indonesia (Askindo), PT Mars Symbioscience Indonesia, Universitas Hasanuddin menyelenggarakan pertemuan di Makassar untuk membangun suatu forum komunikasi antarpemangku kepentingan kakao yang dibentuk dalam Cocoa Sustainability Partnership (CSP) atau Forum Kemitraan Kakao Berkelanjutan. Forum CSP ini bertujuan untuk memecahkan segala permasalahan yang dihadapi dalam pengembangan komoditas kakao Indonesia melalui kolaborasi, integrasi, dan berbagi ilmu pengetahuan yang terkait dengan kakao.

Munculnya gagasan untuk membentuk Forum CSP ini juga didasari oleh kenyataan bahwa berbagai organisasi yang terkait dengan kakao di tanah air, seperti Pusat Penelitian Kopi dan Kakao (Puslitkoka), Universitas Hasanuddin, International Finance Corporation (IFC), The Australian Centre for International Agricultural Research (ACIAR), Asosiasi Kakao Indonesia (Askindo), Asosiasi Industri Kakao Indonesia (AIKI), Sulawesi Cocoa Society (SICOS), Sulawesi Cocoa Research and Development (SCORE), Community Development for Sustainable Agriculture (CDSA), dan lain-lain, yang kurang adanya koordinasi dan komunikasi. Sebagai akibat dari kondisi ini maka upaya pengembangan komoditas kakao yang 


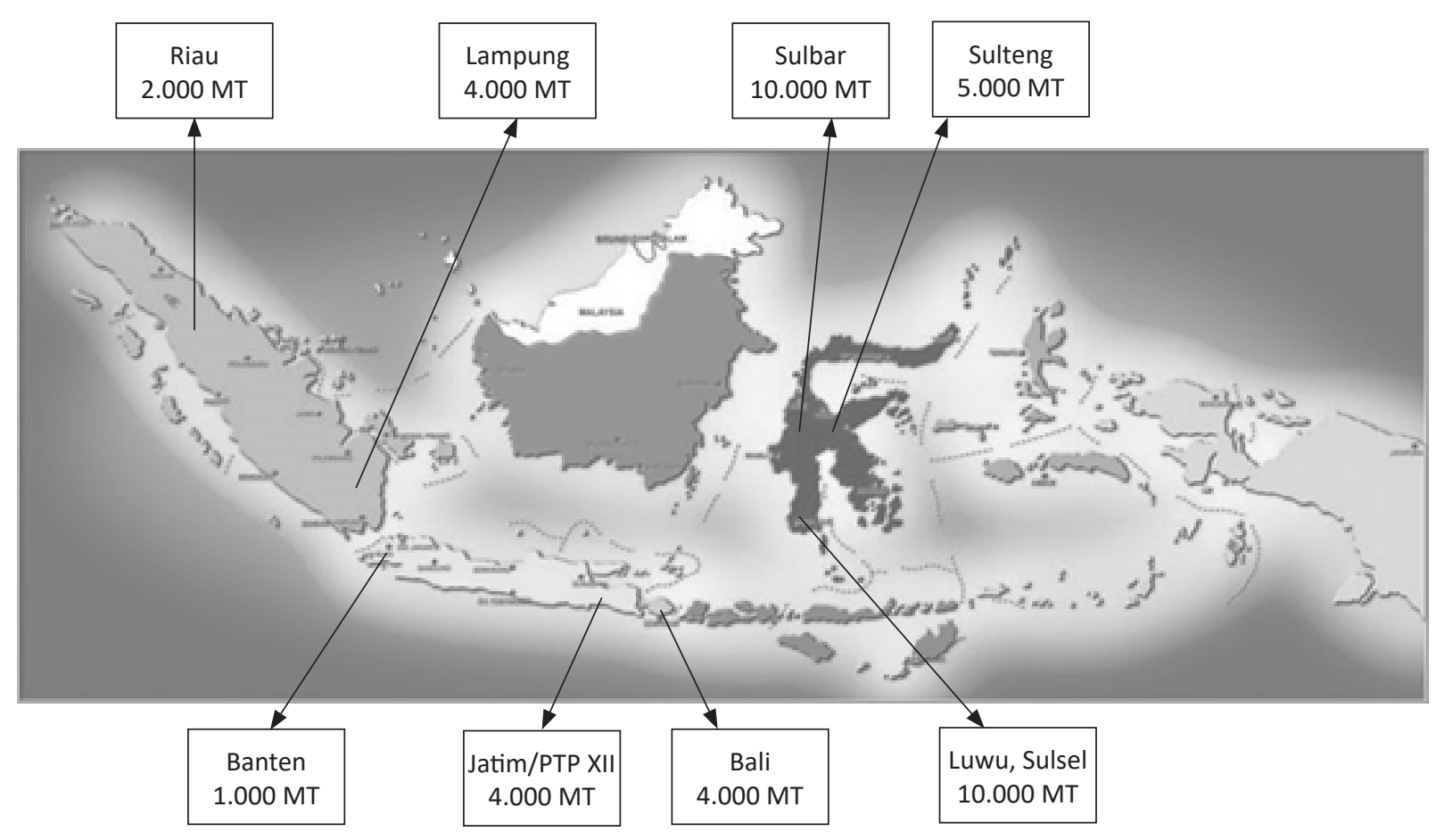

Sumber: Wijaya, 2011.

Gambar 6. Lokasi Percontohan Sertifikasi Kakao di Indonesia

dilaksanakan oleh pemerintah masih saja tersendat dan belum membuahkan hasil yang memuaskan. Oleh karena itu pemerintah seyogyanya memfasilitasi berkembangnya Forum CSP ini.

Forum CSP ini memiliki misi dalam upaya pengembangan komoditas kakao sebagai berikut (a) membangun koordinasi dan komunikasi antarpemangku kepentingan untuk menjalankan program kakao berkelanjutan, (b) identifikasi permasalahan, melakukan prioritas dan mendorong penelitian untuk pembangunan kakao nasional yang berkelanjutan, (c) memberdayakan petani kakao dan kelembagaannya bersama-sama dengan pemangku kepentingan kakao lainnya, (d) mendorong tata niaga yang sehat dan transparan serta kebijakan yang mendukung keberlanjutan kakao nasional, dan (e) mengawal proses sertifikasi kakao berkelanjutan dan implementasinya dalam praktik pertanian yang benar agar bermanfaat bagi semua pihak (Muhtaman, 2010).

Terkaitdenganhal ini, padasaatpembukaaan $T h e 87^{\text {th }}$ Meeting of International Cocoa Council di Denpasar, Bali, pada bulan Maret 2013, Menteri Pertanian menyatakan bahwa Indonesia masih dalam proses menuju penerapan sertifikasi kakao untuk meyakinkan konsumen atas keberlanjutan kakao nasional. Kalangan pengusaha yang tergabung dalam Asosiasi Industri Kakao Indonesia (AIKI) menyambut positif rencana pemerintah yang akan menerapkan sertifikasi terhadap kakao nasional seperti halnya pada komoditas kelapa sawit. Menurut Ketua Umum AIKI diharapkan bahwa pelaksanaan sertifikasi kakao di Indonesia akan berdampak meningkatkan permintaan asing terhadap produk kakao dalam negeri dan sekaligus dapat mendorong petani untuk meningkatkan produksi kakao. Penerapan sertifikasi kakao untuk meyakinkan konsumen atas keberlanjutan kakao nasional ini diharapkan dapat dicapai dengan baik melalui berkembangnya Forum CSP ini.

Forum CSP ini tidak hanya dibentuk di suatu daerah saja tetapi di seluruh wilayah tanah air terutama yang merupakan sentra produksi kakao. Melalui adanya koordinasi dan komunikasi untuk meningkatkan kolaborasi, integrasi, dan berbagi ilmu pengetahuan yang terkait dengan kakao diharapkan akan mampu memecahkan segala permasalahan besar yang dihadapi dalam pengembangan komoditas kakao khususnya yang terkait dengan upaya meningkatkan produktivitas, kualitas, dan keberlanjutan kakao nasional secara nyata.

\section{Kebijakan Dalam Industri Pengolahan Kakao}

Kebijakan pengembangan komoditas kakao nasional tidak dapat dilepaskan dari pengembangan pasca panen yang memiliki nilai tambah dan prospek pemasaran khususnya ekspor yang cerah dengan harga premium. Pada saat ini diperkirakan sekitar 84 persen produksi kakao nasional diekspor dalam bentuk biji kakao mentah sedangkan sisanya sebesar 16 persen diolah di dalam negeri dalam bentuk cocoa powder dan cocoa butter di mana produk ini memiliki nilai jual yang tinggi. Pada Gambar 7 disajikan deskripsi perbandingan nilai jual antara biji kakao mentah dengan produk olahan kakao.

Secara keseluruhan produk olahan kakao memiliki nilai lebih tinggi dibandingkan dengan biji kakao mentah. Di samping itu terkait dengan adanya perkembangan pasar ekspor dan meningkatnya permintaan produk 
kakao dunia merupakan peluang yang harus diraih khususnya oleh masyarakat petani kakao Indonesia. Berkaitan dengan industri pengolahan kakao di Indonesia yang saat ini masih belum optimal, maka Pemerintah Indonesia diharapkan dapat merumuskan berbagai kebijakan dalam upaya pengembangan industri pengolahan kakao nasional.

\section{a. Kebijakan Fermentasi Peningkatkan Mutu Kakao}

Fermentasi merupakan inti dari proses pengolahan biji kakao untuk pembentukan cita rasa khas kakao dengan bantuan mikroba alami agar diperoleh mutu biji kakao yang baik. Proses ini tidak hanya bertujuan untuk membebaskan biji kakao dari pulp dan mematikan biji, namun terutama juga untuk memperbaiki dan membentuk citarasa cokelat yang enak dan menyenangkan serta mengurangi rasa sepat dan pahit pada biji.

Berdasarkan atas kajian dari Pusat Penelitian Kopi dan Kakao Indonesia(2008), komposisi bijikakaoadalah lemak (49-52 persen), protein (6 persen), glukosa (8-14 persen), polifenol (6-12 persen), dan teobromin (0,170,20 persen). Kandungan polifenol dalam biji kakao dengan konsentrasi yang tinggi memberi pengaruh citarasa sepat dan pahit yang berlebihan serta menghambat pembentukan komponen-komponen aroma selama proses penyangraian biji kakao (Nakhrawi, 2011). Harga biji kakao Indonesia relatif rendah dan dikenakan potongan harga dibandingkan dengan produk sejenis dari negara produsen lain. Faktor penyebab mutu kakao yang rendah adalah minimnya sarana pengolahan terutama fermentasi. Proses pengolahan kakao melalui fermentasi akan sangat menentukan mutu produk akhir kakao karena dalam proses fermentasi ini terjadi pembentukan cita rasa khas kakao dan pengurangan cita rasa yang tidak dikehendaki, misalnya rasa pahit dan sepat.

Untuk memenuhi kualitas ekspor biji kakao yang difermentasi, Kementerian Pertanian telah mengeluarkan Standar Nasional Indonesia (SNI) untuk biji kakao. Hasil penelitian menunjukkan bahwa dengan fermentasi yang baik akan dihasilkan pasta kakao, lemak kakao maupun bubuk kakao yang berpengaruh nyata terhadap mutu biji kakao sehingga memenuhi syarat SNI (Towaha, et al., 2012). Namun, tidak semua biji kakao yang diekspor telah memenuhi syarat SNI karena tidak diwajibkan oleh pemerintah. Akibatnya banyak biji kakao yang diekspor kualitasnya di bawah standar SNI yang menyebabkan para importir di negara-negara Uni Eropa maupun Amerika menilai rendah mutu biji kakao asal Indonesia sehingga mengenakan diskriminasi harga (Komisi Pengawas Persaingan Usaha Republik Indonesia, 2009).

Sebagian besar konsumen kakao Uni Eropa pada umumnya adalah industri pengolahan cokelat yang menetapkan berbagai syarat seperti standar biji kakao yang diminati maksimal 100 biji per kg, tidak terdapat serangga di dalam kemasan kakao dan yang terpenting kakao tersebut telah difermentasikan dengan baik. Lebih lanjut, standar mutu kakao internasional yang diprakarsai oleh Food and Drugs Administration (FDA) dari Amerika menyatakan bahwa mutu biji kakao yang diperdagangkan di pasar internasional yang paling utama harus sudah difermentasi dengan kadar air minimal 7 persen. Selain itu, biji kakao harus bebas dari serangga hidup, dikemas dalam tingkatan mutu yang seragam, tidak tercampur dengan kulit dan benda-benda asing lainnya (Departemen Perdagangan Republik Indonesia, 2009).

Perusahaan sertifikasi internasional seperti Rainforest Alliance telah menetapkan berbagai kriteria untuk sertifikasi kakao yang mencakup mulai dari bibit, penyiapan lahan hingga pengolahan biji kakao (fermentasi). Pelaksanaan fermentasi merupakan suatu permasalahan besar dalam industri kakao nasional yang mengakibatkan mutu kakao masih rendah. Produksi kakao nasional sebagian

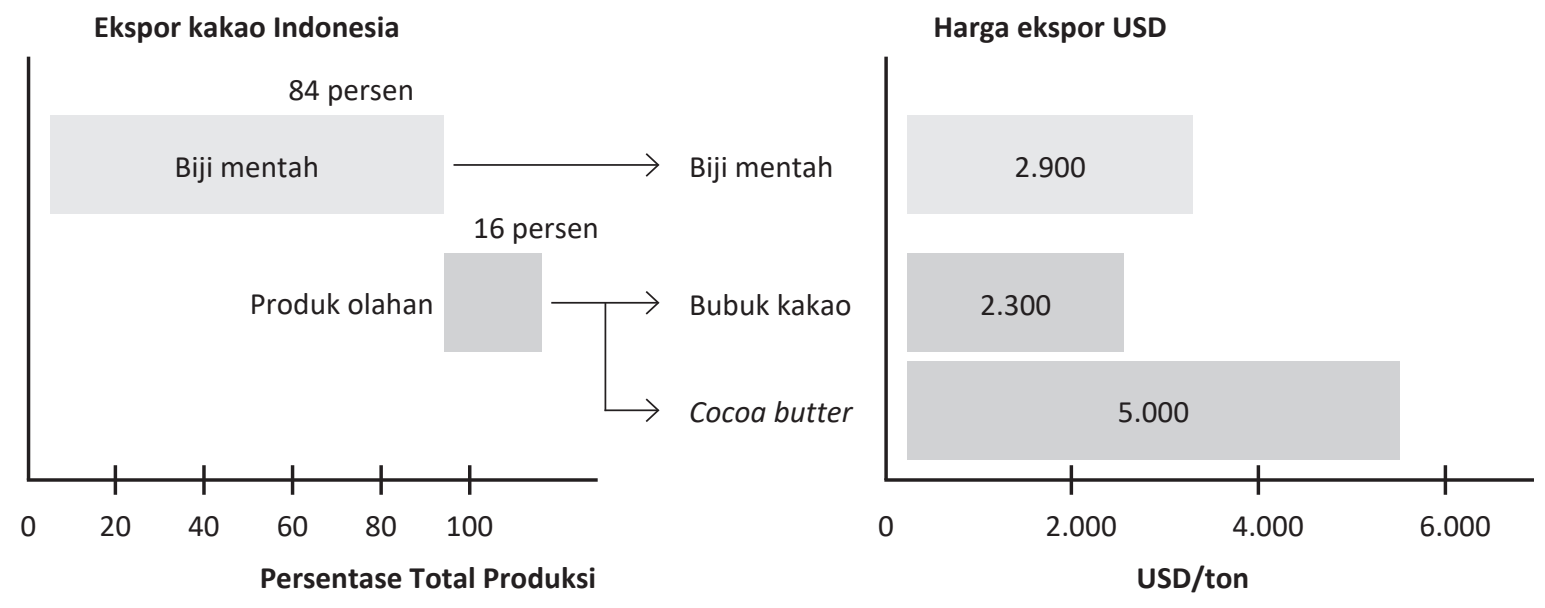

Sumber: Kementerian Koordinator Perekonomian Republik Indonesia, 2010.

Gambar 7. Perbandingan Nilai Ekspor Biji vs Produk Olahan Kakao 
besar (95 persen) merupakan hasil kebun kakao petani, di mana lebih dari 70 persen kakao nasional masih belum difermentasi.

PT Bumi Tangerang Mesindotama telah membuat suatu terobosan dengan membentuk unit kerja yang diberi nama Bumi Tangerang CARE (Cocoa Assistance and Rehabilitation Efforts) biasa disebut dengan BT Care. BT Care ini dibentuk pada tahun 2011 dengan fokus meningkatkan kemitraan dengan petani kakao mencakup pemberian pelatihan, rehabilitasi kebun, fermentasi, dan pembelian biji kakao dari para mitra petani kakao. Program BT Care ini bertujuan untuk mengatasi isu kestabilan dan keberlanjutan kakao dengan cara memfasilitasi petani dalam budidaya sampai dengan fermentasi yang dilakukan sesuai dengan prinsip Good Agricultural Practice (GAP) dan Good Manufacturing Practice (GMP). Dalam hal ini hasil kakao dari petani binaan akan dibeli langsung oleh PT Bumi Tangerang dengan harga sesuai dengan tingkat harga di pasar internasional. $\mathrm{Di}$ lain pihak PT Bumi Tangerang yang bergerak dalam pengolahan kakao ini dapat memperoleh jaminan pasokan kakao dalam kuantitas yang memadai dan kualitas yang tinggi sesuai dengan persyaratan dalam perdagangan internasional. Terobosan yang dilakukan BT Care seyogyanya dikembangkan dan dibina oleh pemerintah dengan melakukan kerja sama kemitraan yang lebih baik dan lebih meluas khususnya di daerahdaerah sentra produksi kakao di tanah air.

Dari hasil pengamatan di lapangan menunjukkan bahwa pelaksanaan fermentasi kakao ini lebih menguntungkan dibandingkan dengan petani yang menjual biji kakao tanpa fermentasi. Masalah klasik yang muncul biasanya petani kakao yang rata-rata memiliki lahan usaha yang sempit, sehingga kurang menguntungkan bila petani melakukan proses fermentasi. Namun, hal ini dapat dengan mudah diatasi bila pelaksanaan fermentasi dilakukan secara kelompok, seperti yang dilakukan oleh masyarakat petani kakao di Kabupaten Tabanan, Bali.

\section{b. Kebijakan Pemberlakuan Bea Keluar dan Tax Allowance}

Pada tahun 2009 industri pengolahan kakao mengalami masa berat ketika kapasitas terpakainya mencapai titik terendah, yakni 54 persen, di mana hanya lima dari 15 perusahaan yang beroperasi (Kementerian Keuangan, 2012). Pada tahun 2010 ekspor biji kakao sekitar 80 persen masih dalam bentuk biji (Suryana, et al., 2014), sehingga pemerintah mulai memberlakukan kebijakan Bea Keluar (BK) biji kakao yang diekspor melalui PMK No. 67/PMK.011/2010 untuk mendorong tumbuhnya industri pengolahan kakao.
Pemberlakuan kebijakan bea keluar (BK) ini ditindaklanjuti dengan Keputusan Menteri Keuangan (KMK) No. 1801/KM.4/2015 tentang penetapan harga ekspor untuk penghitungan Bea Keluar. Dalam KMK tersebut standar harga ekspor biji kakao ditetapkan flat sebesar USD2.854/ton sehingga besaran Bea Keluar ekspor biji kakao saat ini adalah 10 persen. Ketua Umum Asosiasi Industri Kakao Indonesia (AIKI) Piter Jasman belum lama ini menyatakan bahwa pemerintah melalui Kementerian Perdagangan dan Kementerian Perindustrian berusaha akan menaikkan Bea Keluar ini menjadi 15 persen (Supriadi, 2015). Kebijakan ini diambil dengan tujuan untuk menghambat ekspor biji mentah dan mendorong hilirisasi industri kakao.

Dampak diberlakukannya bea keluar melalui PMK No. 67/PMK.011/2010 yang diperbarui dengan PMK No. 75/PMK.011/2012 ini terbukti sangat ampuh mampu mendongkrak tumbuhnya industri pengolahan kakao dalam negeri, di mana tercatat ada enam industri pengolahan yang semula tidak beroperasi bisa kembali beroperasi, tiga industri menambah kapasitas terpasang, lima pabrik kembali beroperasi secara normal, dan satu industri baru, yaitu PT Asia Cocoa Indonesia. PT Asia Cocoa Indonesia ini merupakan perusahaan asal Malaysia (Guan Chong Bhd) yang berinvestasi di tahun 2010 (pasca kebijakan pemberlakuan bea keluar) dan baru beroperasi pada bulan Maret 2011 dengan kapasitas produksi sementara 50.000 ton. Pada periode tahun 2010-2012 Kementerian Perindustrian melansir data volume ekspor biji kakao menurun sangat drastis dan ekspor hasil olahan kakao meningkat tajam sebagaimana disajikan pada Tabel 2.

Pemberlakuan Bea Keluar (BK) atas biji kakao diharapkan mampu menghambat ekspor bahan mentah dan mendorong ekspor kakao olahan. Di samping itu dampak diberlakukannya PMK No. 67/ PMK.011/2010 ini terjadi peningkatan kapasitas industri pengolahan kakao dari 130.000 ton pada tahun 2009 menjadi 150.000 ton pada tahun 2010 dan 280.000 ton pada tahun 2011. Selanjutnya pada tahun 2011 (setahun setelah diberlakukannya PMK) munculah beberapa industri pengolahan kakao seperti PT Barry Callebout dari Swiss dan Archer Daniels Midland Cocoa (ADM Cocoa) dari Singapura. Lebih lanjut untuk mendukung pengembangan industri pengolahan kakao ini pemerintah juga telah memberlakukan kebijakan berupa Insentif Fiskal khusus untuk industri pengolahan kakao yang dibangun di luar Pulau Jawa yang diatur dalam PP No. 52/2011 yang kemudian diperbarui dengan PP No. 18/2015 yaitu berupa Pembebasan Pajak atau Tax Allowance dan fasilitas Pembebasan Bea Masuk atas barang modal. Pembebasan Pajak ini merupakan skema keringanan Pajak Penghasilan atau PPh 
Tabel 2. Volume Ekspor Biji dan Hasil Olahan Kakao Indonesia Tahun 2010-2012

\begin{tabular}{ccccc}
\hline \multirow{2}{*}{ Tahun } & \multicolumn{2}{c}{ Ekspor Biji Kakao } & \multicolumn{2}{c}{$\begin{array}{c}\text { Ekspor Hasil Olahan } \\
\text { Kakao }\end{array}$} \\
\cline { 2 - 5 } & $\begin{array}{c}\text { Volume } \\
\text { (ton) }\end{array}$ & $\begin{array}{c}\text { Trend } \\
\text { (persen) }\end{array}$ & $\begin{array}{c}\text { Volume } \\
\text { (ton) }\end{array}$ & $\begin{array}{c}\text { Trend } \\
\text { (persen) }\end{array}$ \\
\hline 2010 & 432.437 & & 119.214 & \\
\hline 2011 & 210.067 & $-51,4$ & 195.471 & $+64,0$ \\
\hline 2012 & 163.501 & $-22,2$ & 215.791 & $+10,4$ \\
\hline
\end{tabular}

Sumber: Industri Kakao Tumbuh Pesat, 2014.

atas industri/sektor tertentu di daerah, khususnya wilayah di luar Pulau Jawa (Pemerintah Terbitkan Aturan Baru Terkait Keringanan Pajak, 2015).

Dampak diberlakukannya PMK No. 67/PMK.011/ 2010 dan PP No. 52/2011 telah mendorong semakin bertumbuhnya industri pengolahan kakao seperti yang ditampilkan-pada Tabel 3.

Lebih lanjut sebagai dampak diberlakukannya PMK No. 67/PMK.011/2010 yang diperbarui dengan PMK No. 75/PMK.011/2012 dan PP No. 52/2011 yang kemudian diperbarui dengan PP No. 18/2015 ini volume ekspor produk olahan kakao Indonesia terus meningkat sedangkan ekspor biji kakao mengalami penurunan cukup signifikan. Pemerintah optimis bahwa jumlah industri pengolahan kakao akan bertambah menjadi 20 unit usaha dengan kapasitas terpasang 950.000 ton sampai akhir tahun 2015 ini (www.kemenperin.go.id, 2014). Oleh karena itu, pemberlakuan kebijakan ini perlu terus dievaluasi dan didukung oleh kebijakan lain yang terkait untuk meningkatkan iklim usaha industri pengolahan kakao yang semakin kondusif.

\section{c. Kebijakan Peningkatan Konsumsi Cokelat}

Pada tahun 2013 rata-rata konsumsi cokelat Indonesia hanya sebesar $300 \mathrm{gr} / \mathrm{kapita} / \mathrm{tah} u n$. Angka ini jauh lebih rendah bila dibandingkan dengan konsumsi negara-negara tetangga seperti Singapura dan Malaysia yang sudah mencapai $1,0 \mathrm{~kg} / \mathrm{kapita} / \mathrm{tahun}$. Di beberapa negara Eropa dan Amerika Serikat yang tidak memiliki tanaman kakao justru menjadi negara yang mencatatkan konsumsi cokelat masyarakatnya paling tinggi. Saat ini konsumsi cokelat masih didominasi negara-negara Eropa, di mana konsumsi per kapita cokelat terbesar adalah masyarakat Swiss yang mencapai 11,9 kg/kapita/ tahun. Urutan kedua adalah Inggris yang mencapai 9,5 $\mathrm{kg} / \mathrm{kapita} /$ tahun, Austria 8,8 kg/kapita/tahun, Belgia 8,3 $\mathrm{kg} / \mathrm{kapita} /$ tahun, Jerman $8,2 \mathrm{~kg} / \mathrm{kapita} / \mathrm{tahun}$, Norwegia $8,0 \mathrm{~kg} / \mathrm{kapita} / \mathrm{tahun}$, Amerika Serikat $5,5 \mathrm{~kg} / \mathrm{kapita} /$ tahun (Cokelat, 2014). Masyarakat Indonesia selama ini mengenal cokelat terutama yang diproduksi dari negaranegara Eropa, seperti Belgia, Belanda, Jerman, Inggris, Swiss, dan lain-lain. Padahal bahan baku cokelat tersebut berasal dari Indonesia, yang saat ini merupakan negara
Tabel 3. Perkembangan Investasi Industri Pengolahan Kakao di Indonesia Tahun 2010-2011

\begin{tabular}{llcc}
\hline \multirow{2}{*}{ No. } & \multicolumn{2}{c}{ Nama Perusahaan } & \multicolumn{2}{c}{$\begin{array}{c}\text { Kapasitas } \\
\text { Terpasang } \\
\text { (ton/tahun) }\end{array}$} \\
\cline { 3 - 4 } & & $\mathbf{2 0 1 0}$ & $\mathbf{2 0 1 1}$ \\
\hline 1. & PT General Food Industry & 80.000 & 105.000 \\
\hline 2. & PT Bumi Tangerang Mesindotama & 48.000 & 80.000 \\
\hline 3. & PT Davomas Abadi & 40.000 & 40.000 \\
\hline 4. & PT Industri Kakao Utama & 35.000 & 35.000 \\
\hline 5. & PT Maju Bersama Kakao Industry & 24.000 & 24.000 \\
\hline 6. & PT Kopi Jaya Kakao & 24.000 & 24.000 \\
\hline
\end{tabular}

Sumber: Pusat Kebijakan Pendapatan Negara, Badan Kebijakan Fiskal, Kementerian Keuangan, 2012.

produsen kakao terbesar ketiga di dunia.

Rendahnya konsumsi cokelat di Indonesia disebabkan karena masih adanya pemahaman yang keliru dari sebagian masyarakat. Cokelat masih dianggap sebagai makanan yang mahal di samping masih adanya pemahaman yang salah di masyarakat bahwa cokelat menyebabkan caries pada gigi dan bahkan ada yang percaya bahwa cokelat merupakan penyebab badan menjadi gemuk. Ada pula masyarakat yang masih menganggap bahwa cokelat merupakan image sebagai produk makanan yang mahal sehingga cokelat merupakan makanan bagi masyarakat golongan ekonomi menengah ke atas saja. Namun, secara ilmiah dinyatakan bahwa cokelat tidak menimbulkan kecanduan. Hanya saja bagi sebagian orang rasa cokelat yang enak mungkin menyebabkan keinginan untuk mengonsumsinya kembali atau kerinduan di mana hal ini disebut sebagai chocolate craving. Kerinduan akan cokelat bisa terjadi karena aroma, tekstur, maupun kombinasi rasa manispahitnya.

Lebih lanjut ada beberapa kandungan pada cokelat yang berdampak positif dalam kehidupan manusia, antara lain (a) theobromine yang akan menghasilkan hormon serotonin yang akan membuat perasaan senang sehingga kita bisa lebih bersemangat, (b) polifenol akan membantu meningkatkan fungsi kognitif sehingga dapat memudahkan kerja otak untuk menghasilkan ide baru yang kreatif, (c) phenylethylamine yang dapat meningkatkan kadar endorfin pada otak yang akan menghasilkan dophamine, zat yang memberikan perasaan senang dan perbaikan suasana hati, dan (d) phenylethylamine mempunyai khasiat aphrodisiac yang akan membuat perasaan jadi lebih rileks (www. cni.co.id., 2015). Lebih lanjut produk olahan kakao ini mengandung banyak senyawa flavonol yang berfungsi sebagai antioksidan alami atau biasa disebut sebagai flavonoid yang dipercaya dapat mengurangi risiko penyakit jantung atau kardiovaskular (Sudibyo, 2012). 
Meningkatnya konsumsi cokelat nasional erat kaitannya dengan masalah pengembangan agribisnis kakao. Dengan jumlah penduduk saat ini sebesar 240 juta jiwa akan sangat besar pengaruhnya dalam menyerap produk cokelat di dalam negeri. Apalagi hal ini ditunjang dengan semakin meningkatnya pendapatan per kapita masyarakat Indonesia menjadikan peluang pasar cokelat dalam negeri yang potensial. Menurut prediksi dari Kementerian Perindustrian bahwa beberapa tahun kedepan konsumsi cokelat Indonesia dapat meningkat sama dengan India dan China yang mencapai 1,0 kg/kapita/ tahun. Dengan meningkatnya konsumsi cokelat ini diperkirakan akan ada permintaan tambahan sekitar 2,2 juta ton biji kakao per tahun (Industri Kakao Tumbuh Pesat, 2014).

Untuk itu berbagai kebijakan yang berkaitan dalam upaya meningkatkan konsumsi cokelat dalam negeri harus secepatnya dirumuskan secara komprehensif agar peluang pasar yang potensial dapat ditangkap dan membawa peningkatan kesejahteraan petani kakao dan nilai tambah industri pengolahan secara signifikan. Beberapa upaya untuk meningkatkan konsumsi cokelat dalam negeri, antara lain adalah melakukan sosialisasi dan promosi dengan gencar dan terus menerus. Beberapa kegiatan yang bisa dilakukan sebagai bentuk sosialisasi untuk meningkatkan konsumsi cokelat dalam negeri antara lain adalah (a) pendirian "Rumah Cokelat" yang menjual berbagai macam produk makanan cokelat, (b) melakukan promosi kepada masyarakat dengan mendirikan stan di hotel-hotel, promosi kepada murid di sekolah-sekolah, dan (c) Melakukan demonstrasi pembuatan berbagai produk makanan cokelat, dan lain-lain. Melalui kebijakan peningkatan konsumsi cokelat ini sekaligus diharapkan akan dapat mendorong pengembangan hilirisasi kakao dalam negeri dan menciptakan peningkatan nilai tambah produk kakao dan cokelat Indonesia.

\section{SIMPULAN DAN SARAN}

\section{A. Simpulan}

Prospek pengembangan agribisnis kakao di Indonesia tergolong sangat cerah untuk secepatnya mampu menjadi tonggak pembangunan ekonomi dan meningkatkan kesejahteraan masyarakat. Situasi perdagangan kakao dunia pada beberapa tahun terakhir menunjukkan permintaan yang lebih besar dibandingkan dengan produksi kakao dunia sehingga berdampak pada harga kakao dunia yang relatif stabil pada tingkat yang tinggi. Arah kebijakan pengembangan agribisnis kakao kedepan harus diarahkan pada penurunan ekspor kakao Indonesia dalam bentuk biji kakao dan peningkatan ekspor dalam bentuk hasil olahan yang diproduksi oleh industri pengolahan dalam negeri. Untuk mencapai hal ini maka pintu ekspor biji kakao harus dibatasi melalui kebijakan pengenaan Bea Keluar ekspor biji kakao yang tertuang dalam PMK No. 67/PMK.011/2010 yang kemudian diperbarui dengan PMK No. 75/ PMK.011/2012 beserta kebijakan-kebijakan lain terkait dengan pemberian kemudahan dalam pengembangan industri pengolahan kakao. Meningkatnya industri pengolahan kakao ini diharapkan akan meningkatkan nilai tambah, daya saing, maupun efek pengganda yang dapat dinikmati oleh masyarakat Indonesia.

Berkembangnya industri pengolahan kakao di Indonesia diharapkan dapat menerima pasokan bahan baku biji kakao dengan harga yang wajar dari petani. Hal ini akan berdampak merangsang petani kakao dalam melaksanakan budidaya kakao secara lebih intensif lagi sehingga produktivitas dan kualitasnya semakin meningkat. Budidaya kakao maupun industri pengolahan kakao sesungguhnya merupakan satu sistem yang tidak terpisahkan. Pemerintah harus berupaya menciptakan iklim usaha yang kondusif melalui dukungan harmonisasi kebijakan hulu-hilir, yaitu antara aspek budidaya kakao (hulu) dan aspek industri pengolahan kakao (hilir). Harmonisasi kebijakan harus dilakukan secara menyeluruh, terintegrasi, dan sinergis dalam suatu sistem pengembangan agribisnis kakao nasional. Suatu hal yang tidak kalah pentingnya adalah kebijakan-kebijakan yang telah dirumuskan harus diimplementasikan secara konsisten dan dievaluasi secara periodik sebagai umpan balik untuk penyempurnaannya karena perkembangan global agribisnis kakao ini cukup dinamis.

\section{B. Saran}

Momentum meningkatnya investasi baru di bidang industri pengolahan kakao setelah diberlakukannya PMK No. 67/PMK.011/2010 yang kemudian diperbarui dengan PMK No. 75/PMK.011/2012 tidak boleh disia-siakan. Sebaiknya saat ini pemerintah melalui Kementerian Keuangan tidak melakukan perubahan kebijakan secara drastis khususnya mengenai tarif Bea Keluar biji kakao. Hal ini disebabkan karena setiap ada perubahan mengenai kebijakan tarif Bea Keluar biji kakao akan sangat sensitif dapat memunculkan iklim usaha yang biasanya mengarah ke kontra produktif. Momentum yang kondusif untuk berkembangnya industri pengolahan kakao ini harus ditunjang dengan berbagai kemudahan dari pemerintah. Badan Koordinasi dan Penanaman Modal (BKPM) diharapkan dapat memberikan kemudahan izin investasi bagi industri pengolahan kakao, Kementerian Pekerjaan Umum dan Perumahan Rakyat (PUPR) yang tanggap dalam menyediakan infrastruktur yang memadai, Kementerian Energi dan Sumber Daya Mineral (ESDM) yang harus sigap mengantisipasi dalam menyediakan kebutuhan 
energi, serta Kementerian Keuangan yang responsif dalam merumuskan kebijakan besaran Bea Keluar serta insentif fiskal yang kesemuanya diarahkan untuk lebih menarik investor menanamkan modalnya khususnya dalam industri pengolahan kakao di Indonesia.

\section{DAFTAR PUSTAKA}

\section{Buku}

Kementerian Pertanian. (2015). Statistik perkebunan Indonesia 2013-2015, kakao. Jakarta: Direktorat Jenderal Perkebunan, Kementerian Pertanian.

Departemen Perdagangan Republik Indonesia. (2009). Laporan peluang ekspor komoditi kakao di Uni Eropa. Jakarta: Departemen Perdagangan Republik Indonesia.

Kementerian Koordinator Perekonomian Republik Indonesia. (2010). Masterplan Percepatan dan Perluasan Pembangunan Ekonomi Indonesia (MP3EI). Jakarta: Kementerian Koordinator Perekonomian Republik Indonesia.

Wijaya. S. (2011). Manfaat program Gernas Kakao untuk industri kakao. Tangerang: PT Bumi Tangerang Mesindotama.

\section{Jurnal}

Haifan, M. (2015). Dampak kebijakan bea keluar terhadap kinerja industri pengolahan kakao. Jurnal Iptek, 1(1), 1-6.

Hasibuan, A. M., Nurmalina, R., \& Wahyudi, A. (2012). Analisis kinerja dan daya saing perdagangan biji kakao dan produk kakao olahan Indonesia di pasar internasional. Jurnal Tanaman Industri dan Penyegar, 3(1), 57-70.

Limbongan, J. \& Djufry, F. (2013). Pengembangan teknologi sambung pucuk sebagai alternatif pilihan perbanyakan bibit kakao. Jurnal Litbang Pertanian, 32(4), 166-172.

Rubiyo \& Siswanto. (2012). Peningkatan produksi dan pengembangan kakao (Theobroma cacao L.) di Indonesia. Jurnal Tanaman Industri dan Penyegar, 3(1), 33-48.

Sudibyo, A. (2012). Peran cokelat sebagai produk pangan derivate kakao yang menyehatkan. Jurnal Riset Industri, VI(1), 23-40.
Suryana, A. T., Fariyanti, A., \& Rifin, A. (2014). Analisis perdagangan kakao Indonesia di pasar internasional. Jurnal Tanaman Industri dan Penyegar, 1(1), 29-40.

Towaha, J., Anggraini, D. A., \& Rubiyo. (2012). Keragaman mutu biji kakao dan produk turunannya pada berbagai tingkat fermentasi: Studi kasus di Tanbanan, Bali. Pelita Perkebunan, 28(3), 166-183.

\section{Sumber Digital}

Industri.bisnis.com. (2012). Agribisnis kakao: Hentikan pengembangan bibit jenis SE. Diperoleh tanggal 6 Mei 2013, dari http://industri.bisnis. $\mathrm{com} / \mathrm{read} / 20120926 / 99 / 97583 /$ agribisniskakao-hentikan-pengembangan-bibit-jenis-se.

Antoni, F. (2015). Diprediksi industri kakao Indonesia menjadi nomer satu dunia. Seputar Jawa. Diperoleh tanggal 19 Oktober 2015, dari http://seputarjawa.com/8006/2015/01/18/ di-prediksi-industri-kakao-indonesia-menjadinomer-satu-dunia/.

www.btcocoa.com. (2014). Dunia defisit pasokan 1 juta ton tahun 2020. Diperoleh tanggal 27 September 2015, dari http://www.btcocoa. com/news/view/731/Dunia-Defisit-Pasokan-1Juta-Ton-Tahun-2020.

www.cni.co.id. (2012). Agribisnis kakao: CNI ajak masyarakat minum cokelat setiap hari. Diperoleh tanggal 2 November 2015, dari http://www.cni. co.id/index.php/corporate-info/news/beritadaerah/2217-cni-ajak-masyarakat-minumcokelat-setiap-hari.

www.kemenperin.go.id. (2014). Industri kakao tumbuh pesat. Diperoleh tanggal 2 November 2015, dari http://www.kemenperin.go.id/ artikel/ 7473/Industri-Kakao-Tumbuh-Pesat

Komisi Pengawas Persaingan Usaha Republik Indonesia. (2009). Background paper, kajian industri dan perdagangan kakao (pp 30, 3839). Diperoleh tanggal 29 September 2015, dari http://www.kppu.go.id/docs/Positioning_ Paper/positioning_paper_kakao.pdf .

Manurung, S. H. (2012). EksporkakaokeASterusturun. Diperoleh tanggal 6 Agustus 2014, dari http:// industri.bisnis.com/read/20120727/99/88266/ ekspor-kakao-ke-as-terus-menurun .

Nakhrawi, S. (2011). Fermentasi kakao. Diperoleh tanggal 5 Mei 2013, dari http://annakhrawi. blogspot.co.id/2011/09/fermentasi-kakao.html. 
Pusat Kebijakan Pendapatan Negara, Badan Kebijakan Fiskal, Kementerian Keuangan. Jakarta. (2012). Kajian pengembangan perekonomian kakao nasional pasca pengenaan bea keluar biji kakao (pp 8-9). Diperoleh tanggal 6 Oktober 2015, dari http://www.fiskal.depkeu.go.id/2010/adoku/2 012\%5Ckajian\%5Cpkpn\%5Cpublikasi_pkpn_4-6. pdf.

Supriadi, A. (2015). Pemerintah akan kenakan tarif flat bea keluar kakao 15 persen. Diperoleh tanggal 20 Oktober 2015, dari http://www.cnnindonesia. com/ekonomi/20150214173757-92-32155/ pemerintah-akan-kenakan-tarif-flat-bea-keluarkakao-15-persen/

\section{Makalah}

Barani, A. M. (2011). Konsepsi gerakan nasional peningkatan produksi dan mutu kakao (Gernas Kakao). Disampaikan pada acara: Seminar Evaluasi Pelaksanaan Gernas Kakao di Bappenas. Jakarta.

Fahmi. Z. I. (2011). Penggunaan benih kakao bermutu dan teknik budidaya sesuai standar dalam rangka menyukseskan Gernas Kakao 2009-2011. Makassar.

Murniningtyas, E. (2011). Evaluasi gerakan nasional peningkatan produksi dan mutu kakao (Gernas Kakao). Jakarta: Bappenas.

\section{Laporan}

Gusli. S. (2012). Keragaan lapangan tanaman kakao Sulawesi yang dihasilkan dari Somatic Embryogenesis. Pusat Penelitian dan Pengembangan Sumberdaya Alam, Universitas Hasanuddin. Makassar.

Muhtaman, D. R. (2010). CSP's strategy 2010-2014: building synergy for sustainable cocoa industry in Indonesia. Draft Report. Makassar.

\section{Sumber Lain}

Cokelat. (2014). Bangkitnya para penghasil kakao Indonesia, sebuah laporan lengkap. Makassar: Cocoa Sustainability Partnership (CSP).

Peraturan Menteri Keuangan No. 67/PMK.011/2010 tentang Penetapan Barang Ekspor yang Dikenakan Bea Keluar dan Tarif Bea Keluar.

Peraturan Menteri Keuangan No. 75/PMK.011/2012 tentang Penetapan Barang Ekspor yang Dikenakan Bea Keluar dan Tarif Bea Keluar.

Peraturan Menteri Pertanian No. 09/Permentan/ OT.140/ 1/2013 tentang Pedoman Teknis Pembangunan Kebun Induk dan Kebun Entres Kakao. 